\title{
Combating and preventing Cyberbullying: a review of the literature between 2010 and 2020
}

\author{
Alana Anastacia Gonçalves Bayma ${ }^{1}$; Bruno Brandão Pereira Machado ${ }^{2 *}$; Gleysson Paulino Farias \\ da Silva ${ }^{3}$; Mayara Cristy Gonçalves Silva ${ }^{4}$; Pierre Teodosio Felix ${ }^{5}$
}

1-4 Psychology Students at University Center of Vitória de Santo Antão (UNIVISA), Vitória de Santo Antão, Pernambuco, Brazil

5 Professor of Psychology course at University Center of Vitória de Santo Antão (UNIVISA), Vitória de Santo Antão, Pernambuco, Brazil

\begin{abstract}
E-mail adresses: alanaanastacia@hotmail.com (Alana Anastacia Gonçalves), bruno.b.machado87@gmail.com (Bruno Brandão Pereira Machado),gleyssonsiillva123@gmail.com(Gleysson Paulino Farias da Silva),mayara_cristy@hotmail.com (Mayara Cristy Gonçalves Silva), pierrefelix@univisa.edu.br (Pierre Teodosio Felix)

${ }^{*}$ Corresponding author
\end{abstract}

\section{To cite this article:}

Bayma, A.A.G.; Machado, B.B.P.; Silva, G.P.F.; Silva, M.C.G.; Felix, P.T. Combating and preventing Cyberbullying: a review of the literature between 2010 and 2020. International Journal of Sciences. Vol. 2, No. 3, 2021, pp. 19-22. ISSN $2763-5392$.

Received: 10 08, 2021; Accepted: 10 09, 2021; Published: 11 03, 2021

\begin{abstract}
Bullying, once a behavior of contact relationships, was reconfigured by amply socialization in the virtual sphere, where the attack can occur at any time and without physical delimitation, leading to cyberbullying. A global phenomenon that affects different cultures and contexts. Its characteristic is a digital version of violence with an individual or group of people and consists of an act committed aggressively and intentionally using technology to threaten, humiliate, besmirch, of affect good coexistence; shaking mental health and, often, the physical integrity of the victim(s). Causing suicide attempts, social and emotional problems, psychoactive substance abuse, anxiety and depression. This article aims to carry out bibliographic research, based on scholars who have relevant knowledge on the subject, as well as linked files in digital media. And the intention of analyzing the subject in a qualitative and theoretical way in order to understand the phenomenon in question and present the possible consequences of the practice of this act, as well as ways to prevent it.
\end{abstract}

Keywords: Internet. Bullying. Cyberbullying. Virtual Violence.

\section{Introduction}

Cyberbullying is, in other words, a bullying that corresponds to the manifestation of hostile practices (via information technologies). This virtual bullying is intended to belittle, harass and/or persecute someone in an exacerbated way (DIANA, 2019).

Used for the first time by Canadian researcher Bill Besley, cyberbullying happens when an aggressor uses electronic means to harass or assault another person or group of people intentionally and repetitively. The expression is the fusion of the prefix cyber, diminutive of cybernetic - which is reflected to everything that comes from the internet, and the word bully which. The suffix - "ing", in English, refers to a condition of continuous practice. Brazil is among the countries that suffer the most from this phenomenon. It is estimated that a total of 42 million Brazilians has already suffered from cyberbullying, which places Brazil with the highest rate of cyberbullying in the world (DA SILVA, 2018).

Another study, conducted by the IPSOS institute, puts Brazil in second place, behind only India. For a better understanding of the subject, it is necessary to know some words - originated from English - that are part of the language of virtual aggressions. Expressions like hater, sexting, nudes, and revenge porn are some of the most common. Hater comes from hate. Hater is someone who spreads hate online for free and without provocation. Sexting, on the other hand, is the junction of sex and texting, which is the act of and send text messages. Therefore, sexting is the practice of sharing erotic content in messaging apps and on social networks. The word nude is a term used to refer to nude photos. Revenge porn consists of revenge on someone by reclosing photos or videos pornographic or erotic of that 
person (PORFÍRIO, 2019).

Nevertheless, this is a subject little explored by the national scientific community, and compared itself with other countries. The United States is the country that conducts the most scientific research on this subject. Recently, the issue has been increasingly included in the health field, debating the associations between its practices and the consequences of all those involved (FERREIRA E DESLANDES, 2018).

The behavior of users and their interactions with virtual environments point to the need for a theoretical review that dialogues with other ways of conceiving the space, which is now also virtual, besides making relationship with the feeling of anonymity present in these new social arrangements. I view that there are few studies on the subject, the authors point out the importance of conducting new studies to better understand the phenomenon. (FERREIRA E DESLANDES, 2018 ; MALLMANN et al., 2018 ; SCHREIBER and ANTUNES, 2015 ; SOUZA et al,2014)

This article aims to contribute to the awareness and discussion of this problem and its consequences for both the victim and the aggressor. Through a literary review, it proposes measures that can be taken by the school, parents and potential victims in order to combat cyberbullying.

\section{Methodology}

This is a study with data collection based on bibliographic data collection. For this lead, articles were retrieved from the Scientific Electronic Library Online (SciELO), Electronic Journals in Psychology (PEPSIC) and Google Scholar. The inclusion criteria determined for the selection of articles were: texts available in full, articles in Portuguese from 2010 to 2020; dealing with the theme of cyberbullying. Brazilian laws addressing the theme and position of the United Nations International Emergency Fund for Children (UNICEF) were also consulted. All opinions or unreferenced texts served as exclusion criteria in this study.

\section{Results and Discussion}

The advancement of technologies, especially the Internet, has provided endless possibilities of information. Currently, people are connected 24 hours a day on the internet. From the encounter between these technologies and the already frequent conflicts that occur in the school environment - the traditional bullying - cyberbullying is born, which breaks down social and geographical barriers. In this phenomenon, the aggressor hides behind a screen and the conflict migrates, from school to social networks (FERREIRA et al,2017).

According to Azevedo et al (2012):

"(...) cyberbullying is an extension of the schoolyard" (p.12).

Also, according to the authors, the virtual field can prove to be a place where victims of bullying can use the resources and tools to get revenge on those who attack them personally. This phenomenon is especially harmful, because aggression spreads rapidly, due to the speed of access to information on the Internet. In 2008, it was estimated that $68 \%$ of adolescents spend at least one hour on the internet per day. Over the years, this percentage, as well as the time of access, only increased. Young people have one or more mobile phones, which ensures virtually unlimited internet access. The consequence of this is that aggression can occur anywhere and the home itself is no longer a safe place (AZEVEDO et al, 2012).

A crucial actor for the popularization of this type of aggression is the possibility of anonymity. While allowing to reach a large number of people, the technologies allow the aggressor to keep his identity secret. This makes it harder for the victim to face the situation and can cause a feeling of vulnerability. It is also verified a low indictment of denunciation by victims of cyberbullying. Even in cases where the identity of the aggressor is known, younglings do not warn adults for fear of suffering greater retaliation or for fear of losing access to the Internet. Another reason for silence is the belief that adults may underestimate the situation (MALLMANN et al., 2018).

The consequences of cyberbullying are serious and numerous. At first, victims of cyberbullying may exhibit antisocial behavior, isolation and sadness. As time goes by, aggression can result in more serious consequences. In his study, Wendt (2020) points out that:

"Cyberbullying victimization was positively associated with all domains evaluated by THE ICD (anhedonia, ineffectiveness, interpersonal problems, depressed mood, and negative selfesteem)." (p.3).

The victim may also take a more aggressive stance, seeking revenge on his or her aggressor, or against someone he considers to have been conniving with aggression and even, in some cases, aggression against the place where the person was victimized. (FUJITA and RUFFA, 2019).

The consequences, however, are not limited only to victims. Cyberbullying practitioners also show an increase in suicidal thoughts and low levels of self-esteem when compared to students who do not participate in this type of aggression. In addition, there is a damage to the development of some social skills, especially their empathy (WENDT and LISBOA, 2013).

Violence caused by bullying and cyberbullying does not only affect victims and aggressors. According to Da Costa (2015):

"such practice, whether directly or indirectly, ends up also resonating within society, within the family and other institutes."

In many countries, there are already specific laws to combat cyberbullying, where such activities are considered criminal. In these countries, victims of this type of aggression can seek protection, prohibit communication with a specific person or even limit the access of the aggressor to technological devices (UNICEF, 2020).

In Brazil, law 13,185, of 2015, establishes the Program of Combatting up to Systemic Intimidation (bullying), which defines, in its second paragraph, the practice of bullying as: 
"systematic intimidation(bullying) when there is physical or psychological violence in acts of intimidation, humiliation or discrimination." The law lists the attitudes that configure this type of behavior, they are: (1) physical aggressions; (2) personal insults; (3) systematic comments and derogatory surnames; (4) threats by any means; (5) derogatory graffiti; (6) prejudiced expressions; (7) premeditated conscious social isolation; and (8) "pilhérias" (so-called sarcastic or jokes with offensive intentions). Still in the same article, in its single paragraph, it is said that the attitudes described, when performed using technological and communication devices, are acts of cyberbullying and should be treated as acts of bullying. The same law defines program objectives, including the dissemination of information campaigns, training teachers to deal with situations, prevention and combating bullying, and providing psychological, social and legal help, both to victims and aggressors. It is the obligation of educational institutions, clubs and associations to raise awareness, prevent, diagnose and combat bullying (BRASIL, 2015).

More serious cases of cyberbullying are provided for in the penal code in articles 138, 139 and 140. These articles deal with acts against honor, which are punished with detention. Additionally, the victim may demand the payment of moral compensation for the damage suffered thanks to the aggressor. If the aggressor is a minor, responsibility for his/her acts may fall on parents or their educators (D'URSO, 2010).

The responsibility for combating cyberbullying rests with everyone, going beyond the legal sphere. In this respect, the general consensus of the literature is that preference be given to prevention measures rather than punishment (DA SILVA, 2018); (UNICEF, 2020); (FUJITA and RUFFA, 2019) and (D'URSO, 2010).

Parents have enormous importance to prevent the spread of cyberbullying. Inadequate education on the part of parents can make the young person more conducive to practicing or being victimized by virtual aggressions. It is essential that there is quality time between parents and children. They should warn their children about possible problems and encourage them to seek help when they feel attacked (SOUZA et al,2014).

It is the family's obligation, according to the Federal Constitution of 1988:

"(...) ensuring that children, adolescents and young people, with absolute priority, have the right to life, health, food, education, leisure(...)" (BRAZIL, 1988).

Because it associated with various psychological disorders, the prevention of cyberbullying is included in this responsibility. The family should monitor their children's use of electronic devices. Not only check the content it consumes, but also check if they are victims of any virtual aggression. To do so, there are software that can help. Programs that verify the origin of incoming emails, or that filter, monitor, and block inappropriate content and websites; are some of the tools can be used by parents. (CONTI and ROSSINI, 2010)
Next to the parents are the school and the educators. This partnership is very important, because it is known that there is a connection between what happens in the school environment and the aggressions on the Internet. That is why the school environment (both schools and universities) should have a good relationship between students, stimulating respect and social cohesion. Educational establishments should educate teachers, parents and pupils on how to act in cases of cyberbullying and about the legislation relevant to the case. Knowing that there is hesitation to denounce the aggressions, it is important to create easy platforms for students to seek help. Examples are telephone lines and emails dedicated to these cases and that give the whistleblower the possibility of anonymity (SOUZA et al,2014).

The school must define a series of integrated actions to better combat this phenomenon. Another possibility is the creation and rules and disciplinary measures to be taken in the event of their non-compliance. Mediation initiatives, in order to stimulate the participation of students in solving problems, can also be useful (FREIRE et al,2013).

Colleagues and friends also play an important role in combating virtual aggression. They have the power to reinforce or not an aggressor attitude, affecting the probabilities of recidivism. In addition, colleagues are witnesses of what happened and must denounce the aggressions (RONDINA et al., 2016)

There are also measures that must be taken by users to prevent virtual aggressions. You need to be careful with your personal information and avoid sharing your people passwords with other people - even if friends. If you suffer from cyberbullying, it is important that the victim chooses not to reply the aggression, choosing to ignore and block the aggressor. The victim should also try to talk to someone he trusts, or call a rescue service for professional advice. It is interesting to gather evidence to prove that the aggressions occurred (UNICEF, 2020).

\section{Conclusions}

In view of the observed aspects, it is evident the impacts of cyberbullying on the mental and physical health of practitioners and victims. Digitized bullying is more common among adolescents in the school environment, where there is a growing popularize of internet and mobile phone use creates a fertile field for the dissemination of this type of aggression (TOGNETTA and BOZZA, 2012)

Cyberbullying can impair concentration and school performance, as well as cause isolation, depression and suicidal thoughts. It is important to protect and monitor the psychological of the victims, which can become very fragile. Prevention, through guidance and supervision, is still the best way to protect children and adolescents from virtual violence (BENTO, 2019).

Because of the many repercussions of this type of violence, it is not possible to think of individual solutions. We need to think more broadly, including the community as a whole (SCHREIBER and ANTUNES, 2015). 
4 Bayma, A.A.G.; Machado, B.B.P.; Silva, G.P.F.; Silva, M.C.G.; Felix, P.T. Combating and preventing Cyberbullying: a review of the literature between 2010 and $2020 \ldots$

\section{References}

[1] AZEVEDO, J.; MIRANDA, F.; SOUZA, C. H. Reflexões acerca das estruturas psíquicas e a prática do Cyberbullying no contexto da escola. INTERCOM - RBCC. São Paulo, v.35, n.2, p. 247-265, jul./dez. 2012;

[2] BENTO, R.; Cyberbullying - a violência psicológica virtual. 2019. Disponível em: <https://correiodoestado.com.br/artigose-opiniao/renata-bento-cyberbullying-\%E2\%80\%93-aviolencia-psicologica-virtual/354810>. Acesso no dia: 07/10/2021;

[3] BRASIL. Constituição (1988). Constituição da República Federativa do Brasil. Brasília, DF: Senado Federal: Centro Gráfico, 1988;

[4] BRASIL. Lei $n^{\circ} 13.185$, de 6 de novembro de 2015. Diário Oficial da União, Poder Executivo, Brasília, DF, 9 nov. 2015;

[5] CONTE, C.P.; ROSSINI, A.E.; Aspectos jurídicos do cyberbullying. Revista FMU Direito, São Paulo, ano 24, n 34, pg. 46-65, 2010;

[6] CYBERBULLYING: O QUE É E COMO PARÁ-LO. UNICEF. 2020. Disponível em: $<$ https://www.unicef.org/brazil/cyberbullying-o-que-eh-ecomo-para-lo>. Acesso em: 24/09/2021;

[7] D'URSO, C.; Cyberbullying: um desafio para o direito. Ordem dos Advogados do Brasil - São Paulo (OAB SP), 2010 Disponível em: $<$ https://www.oabsp.org.br/comissoes2010/gestoesanteriores/acaosocial/artigos/ARTIGO\%20-\%20CYBERBULLYING.pdf/do wnload>, Acesso em: 07/10/2021>

[8] DA COSTA, E.A.; Cyberbullying e seus efeitos na sociedade. Direito Net, 2015. Disponível em: $<$ https://www.direitonet.com.br/artigos/exibir/8841/Cyberbull ying-e-seus-efeitos-na-sociedade>. Acesso em: 07/10/2021;

[9] DA SILVA, C. Cyberbullying: o que é? Politize! 2018. Disponível em: $<$ https://www.politize.com.br/cyberbullying-oque-e/>. Acesso em: 23/09/2021;

[10] DIANA, D. Cyberbullying. Toda Matéria, 2019. Disponível em: $<$ https://www.todamateria.com.br/cyberbullying/>. Acesso em: 06/10/2021;

[11] FERREIRA, M.; ROCHA, V.L.; IBIAPINA, C.C.; Por que precisamos falar sobre bullying e cyberbullying. Revista Médica de Minas Gerais, v. 27 n 3. pg. S73-S76, 2017;

[12] FERREIRA, T.; DESLANDES, S.; Cyberbullying: conceituações, dinâmicas, personagens e implicações à saúde. Ciência \& Saúde Coletiva, v. 23 n¹0. pg. 3369-3379, 2018;

[13] FREIRE, I.; ALVES, M.M.; BREIA, A.P.; CONCEIÇÃO, D.; FRAGOSO, L. Cyberbullying e Ambiente Escolar: Um Estudo Exploratório e Colaborativo entre a Escola e a Universidade. Revista Portuguesa de Pedagogia, v. 47, n. 2, p. 43-64, 2013;

[14] FUJITA, J.; RUFFA, V.; Cyberbullying: família, escola e tecnologia como stakeholders. ESTUDOS AVANÇADOS v. 33 $n^{\circ}$ 97, 2019;
[15] MALLMANN, C.L.; LISBOA, C.S.M.; CALZA, T.Z.; Cyberbullying e Estratégias de Coping em Adolescentes do Sul do Brasil. Acta.colomb.psicol. v.21, n¹, pg. 13-22, 2018;

[16] PORFÍRIO, F.; Cyberbullying. Mundo Educação, 2019 Disponível em: $<$ https://mundoeducacao.uol.com.br/sociologia/cyberbullying. htm>. Acesso em: 27/09/2021;

[17] RONDINA, J.M.; MOURA, J. L.; CARVALHO, M.; Cyberbullying: o complexo bullying da era digital. RE. SAÚD. DIGI. TEC. EDU., Fortaleza, CE, v. 1, n. 1, p. 20-41, jan./jul. 2016;

[18] SCHREIBER, F.C.; ANTUNES, M.C.; Cyberbullying: do virtual ao psicológico. Bol. Acad. Paulista de Psicologia, São Paulo, v. 35, nº 88, pg. 109-125, 2015;

[19] SOUZA, S.B.; SIMÃO, A.M.; CAETANO, A.P.; Cyberbullying: Percepções acerca do Fenômeno e das Estratégias de Enfrentamento. Psicologia: Reflexão e Crítica, v. 27. $n^{\circ} 3$, pg. 582-590, 2014;

[20] SOUZA, S.B.; SIMÃO, A.M.; FRANCISCO, S.M.; Cyberbullying: incidência, consequências e contributos para o diagnóstico no ensino superior. @mbienteeducação, São Paulo, vol. 1, no 7, pg. 90-104, 2014;

[21] TOGNETTA, L.R.; BOZZA, T.C.; Cyberbullying: um estudo sobre a incidência do desrespeito no ciberespaço e suas relações com as representações que adolescentes têm de si. Nuances: estudos sobre Educação, v. 23, nº 24, pg 162-178, 2012;

[22] WENDT, G. Associações entre vitimização por cyberbullying e sintomas de depressão em jovens adolescentes. J Bras Psiquiatr. Paraná, v. 70 n. 2; pg. 157-161; agosto, 2020;

[23] WENDT, G.W.; LISBOA, C.S.M.; Agressão entre pares no espaço virtual: definições, impactos e desafios do cyberbullying. Psicologia Clínica, Rio de Janeiro, v. 25, n 1 , pg. 73-87, 2013. 